\title{
COMPATIBILITY BETWEEN PHILOSOPHY AND MAGIC IN THE WORK OF ALBERTUS MAGNUS
}

\author{
Compatibilidad entre Filosofía y Magia en la obra de Alberto Magno \\ Rinotas Athanasios \\ Kapodistrian University of Athens (Greece)
}

\begin{abstract}
Albertus Magnus (1193?-1280), also known as doctor universalis, delved into several fields of science and philosophy, a pursuit which resulted in a massive production of works. Within these works, however, one discerns a provocative paradox, in which a cleric is involved in a forbidden art: magic. In this paper I argue that a paradox of this kind can be justified and explained in terms of philosophy. To this end, I advance three case studies to shed light on the afore-mentioned problem. First, I scrutinize indirect and direct sources in order to clarify Albertus's relation to magic, thus addressing whether it is possible to trace any supportive data that permits a connection between magic and philosophy. Next, I show that this connection is achievable, since some parts of Albertus's philosophy, such as psychology, cosmology and the liberum arbitrium, seem to be associated with magia naturalis in terms of astrology. Finally, I argue that the German philosopher was not successful in legitimizing magic through philosophy, and thus failed to prove himself a unique pioneer of an innovative body of knowledge.
\end{abstract}

Keywords: Albertus Magnus, Magic, Astrology, Science, Philosophy.

\section{RESUMEN}

Alberto Magno (1193?-1280), también conocido como doctor universalis, profundizó en distintos campos de la ciencia y la filosofía, una búsqueda que dió como resultado una producción masiva de obra. No obstante, en este conjunto de obras uno puede descubrir una provocativa paradoja, en la que un clérigo se relaciona con un arte prohibido como la magia. En este artículo, mantengo que una paradoja de este tipo se puede justificar y explicar en términos filosóficos. Con este fin, presento tres estudios de caso que pretenden aportar algo de luz sobre el problema ya aludido. En primer lugar, investigo las fuentes directas e indirectas, para establecer la relación de Alberto con la magia. De este modo, planteo la posibilidad de aportar datos que permitan una conexión entre la magia y la filosofía. Posteriormente, mostraré cómo esta conexión es viable debido a que algunas partes de la filosofía de Alberto, como la psicología, la cosmología o el liberum arbitrium parecen estar asociadas con la magia naturalis en términos de astrología. Finalmente, argumentaré sobre las razones que impulsaron al filósofo alemán a evitar legitimar la magia a través de la filosofía, y que le impidieron mostrarse como un singular pionero de un conocimiento innovador.

Palabras clave: Alberto Magno, Magia, Astrologia, Ciencia, Filosofía.

References from indirect sources that relate Albertus Magnus to magic are easy to find. Specifically, many of his contemporaries have mentioned his involvement in magic, like his pupil Ulrich Engelbrecht (1220-1277), who calls him expertus in magia, Thomas of Cantimpré (1201-1272) who alludes to Albertus's connection with magic in his work Bonum univer- 
sale de proprietatibus apum and Johannes Becanus who cites that he was magnus in nigromantia, maior in philosophia sed maximus in theologia ${ }^{l}$. Later, during the $15^{\text {th }}-16^{\text {th }}$ centuries we encounter the figure of Johannes Trithemius (1462-1516) attempting to defend himself against accusations of magic by declaring that he is misjudged in the same way Albertus was. In Trithemius's own words he informs us that «he (Albertus) is unjustly regarded by the unlearned as a magician and devotee of superstition. For he was not ignorant of the magic of nature and he had innocently read and mastered a great number of superstitious books by depraved men. For not the knowledge but the practice of evil is evil ${ }^{2}$.»By the same token, Johannes Butzbach, Trithemius's defender, affirms that Albertus «being a saint and a true catholic was interested in natural magic and performed many experiences and discoveries, but the vulgar not understanding them considered him a necromancer ${ }^{3} »$. Thus far, these indirect sources offer a compelling account for the consideration that Albert was indeed involved in magic, yet not with magic of the demonic kind but of the kind which deals with nature.

Further interest is raised when we discover the accounts of Albert's biographers. It is worth noting that till the $15^{\text {th }}$ century no official attempt had been made to compile a biography of Albertus Magnus. However, in the afore-mentioned century the Dominican order tried to win canonization for Albertus Magnus and subject to these conditions three vitae were composed by Dominican friars. The first was written in 1487 by Peter of Prussia titled Legenda venerabilis domini Alberti Magni. The second vita was presented a year later by Rudolph of Nijmegen to the monks at Pforzheim in Baden. The last was composed by the Dominican poet and friar Jacobus Magdalius in 1490, whose work Legenda compendiosa et metrica venerabilis domini Alberti Magni describes Albertus's life in a metrical fashion ${ }^{4}$. Meanwhile, it must be noted that behind these compositions lies the figure of Jacob Sprenger whose authority might have played a key role as far as the objectivity of the texts is concerned. During the $15^{\text {th }}$ century, magic enjoyed a certain popularity amongst scholars and common people, whilst, commensurately, a thriving oral tradition connected Albertus Magnus with magic. Sprenger thought that Albertus's canonization would furnish his more controversial works with the proper measure against the threat of the rising magical arts. He thus had to clean Albertus's name from any suspicion of magic in order to stop this on-going trend. In all these biographies it is conceded that Albertus was in fact involved in magic, yet the intriguing part is the reasoning each author provided. According to Peter of Prussia, for example, in the course of Albertus's lifetime many heresies had appeared which exercised the magical arts, thus winning the admiration of the people through the false miracles they produced. Accordingly, Albertus was obliged to study the books of the magicians and the necromancers so as to identify the falsehood and unveil the fraud ${ }^{5}$. So, it was due to pure ignorance and vicious envy that Albertus was associated with magic by succeeding generations. His main purpose, in actuality, was to offer his services against the threat of the heresies. Invariably, this oral tradition, already mentioned, is not to be taken lightly. This is especially so given that many popular stories circulated amongst the people thus influencing vulgate view. One classic instance of this is the vernacular poem Es war ein Kung in Frankreich, which describes the

1 Collins, David J., «Albertus Magnus or Magus? Magic, Natural Philosophy and Religious Reform in the Late Middle Ages», Renaissance Quarterly, 63/1 (2010), p. 17.

2 Thorndike, Lynn, A History of Magic and Experimental Science, vol. II, New York, Columbia University Press, 1923, p. 550.

3 Zambelli, Paola, White Magic, Black Magic in the European Renaissance, Leiden, Brill, 2007, p. 88.

4 Collins, David J., pp. 7-8.

5 Ibid., p. 9. 
efforts made by Albertus to kidnap a princess and protect her using his magical powers. Another story speaks of Albertus's pupil, Thomas Aquinas, destroying his teacher's automaton when he heard it speaking to him ${ }^{6}$.

The only thing that is certain from the above sources is the fact that Albertus Magnus had dealt with magic. Even if this happens to be only in a superficial way, it would not be reckless to say, that, in the consciousness of the scholars and the common people, Albertus was associated with magic. Nevertheless, utilizing the following two facts it can be argued that it is not possible to reach any tangible conclusions regarding our above case. Firstly, Sprenger is highly likely to have manipulated the Dominican friars in order to produce a picture of Albertus which satisfied his own agenda and desires. Secondly, the vernacular Albertian stories may only legitimately be regarded as plain rumours.Though lacking scientific validity, these two facts bring into relief the necessity for a study of Albertus's genuine works.

The study of the works of Albertus Magnus indicates that the German philosopher held no stable thesis regarding magic. In particular, the texts belonging to natural philosophy express a more liberal position on the subject in comparison to the theological ones. In Summa theologiae he admits that magic is an act of demons and as such it must be denounced ${ }^{7}$. Furthermore, in Commentarii in secundum librum sententiarum he cites that the use of magic is evil and divulges apostasy from faith, for whatever is performed and accomplished is due to demons $^{8}$. It is quite obvious that in these works Albertus equates magic with maleficium and leaves no space for it to be interpreted differently. However, his thesis appears to conflict with such an interpretation by his reference to the Biblical Magi; for his rhetoric style acquires a less stringent stance, implying a propensity for compromise on the topic. For Albertus, the Biblical Magi have nothing to do with evil magic and maleficium, and he asserts that a Magus must not be considered the same as a mathematicus or a maleficus or any other practitioner of this kind. Next, in Enarrationes in Evangelium Matthaei we encounter the first instance of a connection of magic with nature. Since Magi know and conjecture things from the inevitable processes of cause and effect in nature, they also have the ability to predict and produce marvellous things ${ }^{9}$. Moreover, in Commentarii in librum Danielis prophetae he clearly states that the Magi are masters who philosophize about the universe and thus must be held as astronomers who seek the future in the stars ${ }^{10}$.

6 Sighart, Joachim, trans. T. A. Dixon, Albert the Great, of the Friar Preachers: His Life and Scholastic Labours, London, R. Washbourne, 1876, pp. 127-128 and Collins, David J., p. 17.

7 Summa theologiae, P. II, tractatus viii, quaestio 30: «Dicendum, quod revera hujus modi illusiones fiunt a daemonibus et a maleficis arte daemonum: hoc enim expresse dicunt Sancti: et communis est omnium opinio et docetur in necromantia in parte illa quae dicitur de Imaginibus et annulis et speculis Veneris et sigilis daemonum Achot Graeco et Grema Babylonico, et Hermete Aegyptio: et invocationes ad hoc ordinatae describuntur in libro Hermogenis et Phileti necromanticorum, et in libro qui dicitur Almandel Salomonis».

8 Commentarii in secundum librum Sententiarum, distinctio vii, F, articulus 12, 164: «dicendum, quod in talibus est apostasia vel oris, vel operis. Si enim per invocationes, conjurationes, sacrificia, suffumigationes, et adorationes fiunt, tunc aperte pactum initur cum daemone, et tunc est apostasia oris ibi. Si autem non fit nisi opera simplici, tunc est apostasia operis: quia illud opus exspectatur a daemone: et exspectare aliquid a daemone vel velle aliquid percipere per ipsum, semper est fidei contumelia, et ideo apostasia».

9 Enarrationes in Evangelium Matthaei $(i-x x)$, caput ii-I, 61: «...Nec sunt Magi malefici, sicut quidam male opinantur. Magus enim et Mathematicus et Incantantor et Maleficus sive Necromanticus et Ariolus et Aruspex et Divinator different. Quia Magus proprie nisi magnus est, qui scientiam habens de omnibus necessariis, et effectibus naturarum conjecturans, aliquando mirabilia naturae praeostendit et educit».

10 Commentarii in librum Danielis prophetae, caput i-20, 465: «Magi dicuntur secundum Hieronymum, quasi magistri, qui philosophantur de universis, magi tamen specialiter astronomi dicuntur, qui in astris futura rimantur.» 
To my mind, this is unequivocally a crucial point concerning Albertus's attitude towards magic, primarily because he introduces a new kind of magician whose philosophical background provides a legitimate form of magic. That is to say magia naturalis. Natural magic is derived from nature itself and especially from the influence of the stars on the sublunar world. Through this influence the occult virtues of natural beings were revealed and could be used in order to produce marvels of nature. Albertus refers to this kind of magic in his works which discuss natural philosophy. As a result, he admits in De vegetabilibus et plantis that there are several herbs which have divine properties and effects, like betonica which strengthens one's capacity for divination, and verbena which is used for erotic purposes ${ }^{11}$. In like manner and in the same work, Albertus explains the procedure by which plants acquire their properties via a combination of five virtues. Amongst these is included the influence of the stars. Regarding the matter of occult virtues in animals, Albertus offers numerous examples in his work $D e$ animalibus, where several parts of animals appear to have wondrous properties for humans. For example, the eyes of an eagle are of benefit to the eyes, and the skin of a lion may be used as a means of protection. Yet, a more radical idea is expressed in De mineralibus where he admits that, for the purposes of attaining knowledge about the occult virtues of minerals, we need help from the sciences of magic and astronomy ${ }^{12}$. In another part of the work he refers to the seven known minerals used during the alchemical procedure, gaining their properties from the seven planets of the solar system ${ }^{13}$. Of course, the Albertian references which allow us to connect the performance of magic to the stellar influences are far more numerous, but it is time to focus on examination of the second case study, which has to do with the question of how Albertus's magical astrology is compatible with his philosophy.

First of all, the astrological influence was constructed on a strong Aristotelian foundation, which in turn provided the most fertile ground for it to be reconciled with theology. In particular, Albertus accepts the Aristotelian description of the heavens as being created from a nobler immaterial element, distinct from the four known ones that form the world of the earth ${ }^{14}$. Due to this immaterial element the stars are of an incorruptible, unchangeable and eternal nature, and as such, it was quite logical that the superior celestial spheres could influence the inferior material bodies. In Albertus's works the influence is described as a result of a mechanism which may be interpreted in either an Aristotelian or a Neoplatonic fashion. In the first case, the prime mover or intelligence moves the first heaven and via the first heaven also moves the celestial bodies that are contained therein. By this method, the celestial spheres become the vessel through which influence is transmitted to the corruptible world. Consequently, the movement of the heavens creates the four elements of the inferior world, which, as they mix, form more advanced species of life-like minerals, viz. plants and animals. Now, given the fact that the generation of these forms of life is subject to stellar motion, it becomes

11 De vegetabilibus et plantis, liber v, tractatus ii, caput vi, 158: «Sed quod oportet adjungere, est quod etiam quaedam habere videntur effectos divinos, quos hi qui in magicis student, magis insectantur, sicut betonica divinationem praebere dicitur, et verbena quae amorem: et ea quae vocatur herba meropis quae dicitur aperire seras clausas.»

12 De mineralibus, liber ii, tractatus iii, caput I, 48: «Antiquorum enim sapientium scripturam de sigilis lapidum pauci sciunt, nec sciri potest nisi simul et astronomia et magica et necromantiae scientiae sciantur.»

13 De mineralibus, III, caput 6, tr.1: «Hoc autem ab his alchemici videntur accepisse, asserentes lapides praetiosos stellarum et imaginum habere virtutem: septem autem genera metallorum formas habere secundum septem planetas inferiorum orbium.»

14 De causis et proprietatibus elementorum et planetarum, I, tr.1, cap.1: «Est enim quoddam elementum primum corporum efficiens et ingrediens compositionem per substantiam et esse, sed influens omnibus tam compositis quam simplicibus suas virtutes... alia autem elementa quae materialiter sunt ingredientia compositum, et sunt primae corporum materiae et sunt quattor...» 
clearly conceivable how the macrocosm affects the microcosm. In the second case, the German philosopher justifies the influence of the stars through a light ${ }^{15}$, probably meant in a Neoplatonic way. Specifically, the first cause appears as a source from which light is emanated and cast upon all of creation. This light must be regarded as a means for establishing harmony and order in both worlds, superior and inferior. In these worlds the beings that are closer to the first cause have a purer and more divine nature, in comparison to the more distant ones. Thus is constructed a hierarchy of life-forms where light unifies the cosmos and empowers the superior beings to impact the inferior by virtue of their proximity to it.

It is to be mentioned, however, that this philosophical syncretism between Aristotelianism and Neoplatonism can be vindicated, if we consider two facts. Firstly, at the end of Aristotle's Metaphysics was added the Liber de causis. Later this work was proven to be Neoplatonic text probably written by Proclus and therefore must be held as a spurious work of Aristotle ${ }^{16}$. So, Albertus was interpreting Aristotle in the light of Neoplatonism, providing a theatrical cosmology, where the scenery is Aristotelian and the action Neoplatonic. Furthermore, we should consider the impact of Saint Augustine's theology on Albertus's effort to reconcile philosophy with theology. For Albertus it was clear enough that Aristotle's philosophy shared common ground with many theological doctrines. His main aim was to promote the view that both disciplines could speak of the same thing using different arguments, without provoking one another. In order to achieve this and expose the parallels between the disciplines, Albertus might have imported the Augustinian tradition into Aristotle's cosmology. Another indication of this syncretism may be detected via the loose usage of the term describing the first principle. Albertus uses four different terms to express the first principle that sets things in motion; in some works he calls it superior motus and unicus motor and in others intellectus and causa prima.

The practice of such a cosmology allowed Albertus to combine magic with astrology on various occasions. This occurs mostly in relation to the art of magical images, commonly known as talismans. A talisman is created by an image or a seal being engraved on the surface of a stone or metal at a favourable moment, viz. when the celestial influence would be at its zenith. On completion of this procedure, the engraved stone or metal can be suitably used so as to produce marvels and extraordinary spectacles. However, in his effort to explain how the images and seals engraved on stones worked, he admitted that in order to achieve this, help from other practices like necromancy, magic and astrology was required. The German philosopher knew that these powers could not be explained by physical laws, and perhaps his personal experience drove him to seek an answer among these practices. More light has been shed upon this topic by the recent study of Darrel Rutkin. Rutkin, quoting Albertus's genuine text De mineralibus and the dubious Speculum astronomiae, argues that talismans are associated with natural philosophy in terms of astrology ${ }^{17}$. In particular, he mentions that in both works someone may distinguish a tendency on Albertus's part to legitimize image magic by means of an astrologizing Aristotelian natural philosophy. This is due to the fact that he accepts another type of image magic apart from the necromantic type. This other image

15 De natura et origine animae, I, tr.1, cap.5: «Et ideo complementum ultimum quod est intellectualis formae et substantiae non per instrumentum neque ex materia sed per lucem suam influit intellectus primae causae purus et inmixtus.»

16 Williams, Steven J., «Defining the Corpus Aristotelicum: Scholastic Awareness of Aristotelian Spuria in the High Middle Ages», Journal of the Warburg and Courtauld Institutes, 58 (1995), pp. 34-38.

17 Rutkin, Darrel H., «Astrology and Magic» in Irven M. Resnick (ed.), A Companion to Albert the Great: Theology, Philosophy and the Sciences, Leiden-Boston, Brill, 2013, pp. 451-505. 
magic takes its power solely from the celestial influences. In Speculum astronomiae we find a reference to this from the Magister Speculi: «the third type is that of astrological images (imagines astronomicae), which eliminates the filth of necromancy, does not have suffumigations or invocations and does not allow exorcisms or the inscription of characters, but obtains its power solely from celestial figures.» ${ }^{18}$ Plenty of evidence can also be drawn from the genuine work of the De mineralibus where Albertus writes: «the first principle of the science of Magi is that everything which comes to be by nature or art is moved at first by celes-

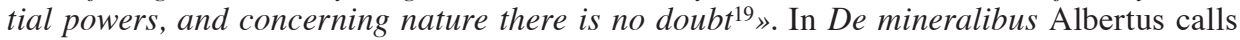
talismans magicae imagines, and includes them in the art of necromancy. However, two things are to be stressed at this point. Firstly, Albertus uses the term of necromancy in a loose way, as Burnett has suggested ${ }^{20}$; and secondly, De mineralibus is not as liberal in its expression as Speculum, which, given the fact that the latter was anonymous, may be deliberate. Still, in both cases it becomes clear that Albertus attempts to use the philosophical cosmology of Aristotle and Neoplatonism with the aim of legitimizing the practice of image magic through astrology.

Apart from cosmology, this astrological magic claims legitimization by means of not opposing the philosophical principles of psychology nor the matter of liberum arbitrium. According to Albertus' psychology, the soul of a human being is incorporeal and is constituted by a dual intellect, the agent and the possible. The interaction of these two enables the soul to become receptive to illumination. As soon as the soul reaches the stage of becoming an intellectus assimilativus, it is open to receive the light from both the intelligences and the first cause and thus enjoy the highest happiness. From this brief description it is easy to understand that the human soul is of divine origin. Consequently, if we take the influence of the stars for granted, then we are in danger of accepting a cosmos that works in a deterministic way and leaves no space for God and the human free will to act. Albertus seems to have realized the problems that emerge from the celestial influences and comments in several works on the subject in order to provide a solution. First of all, the fact that the human soul is of a divine origin means that it plays a decisive role; for it cannot be equated with that of immersed beings such as plants and minerals, whose soul can be fully influenced by the stars. Albertus refers to the afore-mentioned subject in his Summa theologiae by saying, «this quality of the stars (i.e. influentia) is capable of attracting bodies and of changing even the souls of brutes; but it cannot change nor attract with compelling necessity the soul and the will of man. These are created in freedom, after the image of God, and are the masters of their own actions and choices $^{21}{ }_{\gg}$.The interesting part in these words is where he declares that the human soul and will cannot be influenced by the stars in terms of necessity, but still they are not immune to them. If this is the case, then what really happens? Albertus enlightens us even further in his Super Ethica, where he claims: «the will, which is the principle of our actions, by which we

18 Zambelli, Paola, The Speculum astronomiae and its Enigma: Astrology, Theology and Science in Albertus Magnus and his Contemporaries, Dordrecht, Kluwer Academic Publishers, 1992, p. 247: «Tertius enim modus est imaginum astronomicarum, qui eliminat istas spurcitias, suffumigationes et invocationes non habet, neque exorcizationes aut characterum inscriptiones admittit, sed virtutem nanciscitur solum modo a figura coelesti.»

19 De mineralibus, II, caput 3, tr.3: «Est autem principium in ipsa scientia omnia quaecumque fiunt a natura vel arte, moveri a virtutibus coelestibus primo: et hic de natura non est dubium.»

20 Burnett, Charles, «Talismans: Magic as Science? Necromancy among the Seven Liberal Arts», in Charles Burnett (ed.), Magic and Divination in the Middle Ages: Texts and Techniques in the Islamic and Christian Worlds, Ashgate, 1996, p. 3.

21 Summa theologiae, P. I, tractatus xviii, quaestio 68: «Talis enim stellarum qualitas trahere potest corpora et mutare animos etiam plantarum et brutorum, sed animam et voluntatem hominis, quae ad imaginem Dei in liberta oactione, licet forte eatenus qua anima inclinator ad corpus secundum potentias quae affiguntur organis (sicut sunt potentiae animae sensibilis et animae vegetabilis) a tali qualitate trahi possit.» 
are good or bad, is a power of the rational soul; and thus it is clear that we are not compelled by necessity to be good or bad by the disposition of our birth according to the effects of the stars, but rather only in so far as the stars implant certain dispositions in the nature of our body, which has some tendency toward anger and concupiscence; but it is not by necessity that the soul follows this tendency ${ }^{22}$ ». From what has been said thus far, it follows that it is up to humans to become good or bad, and this appears to depend on the way we act. Albertus says as much in De mineralibus: "For in man there is a two-fold principle of action, nature and will; nature is ruled by the stars and will on the other hand is free. But unless will puts up a concrete defense, it is bound to be influenced by nature and hardened, so that it too, like nature, will be inclined to act according to the motions and configurations of the stars ${ }^{23}$ ». These citations enable us to understand the significance of liberum arbitrium in explaining the impact of celestial influences on humans. Before proceeding any further, it must be mentioned that Albertus does not identify liberum arbitrium with the will or the intellect. In order for someone to act, at the first stage, the intellect presents the options that can be made when coupled with the will, which desires the best outcome from the options proposed. At the second stage, liberum arbitrium chooses one of these options ${ }^{24}$. Considering now the influence imposed by the stars, it is possible that the will may incline to the bad or the good dispositions that are infused throughout the body by the celestial spheres. However, it is still up to human liberum arbitrium whether someone will succumb to these dispositions or not. From this perspective, the stars and their influences provide nothing more than mere signs. Ultimately, it depends on us to determine our destiny through our actions and choices. In this case, Albertus utilizes arguments from the area of ethics and psychology in order to legitimize magical astrology. Finally, this lack of necessity, which is referred to the stellar influence, brings to mind the well-known dictum from Ptolemaeus, Vir sapiens dominabitur astris, an argument which was probably the subconscious basis of Albertus's astrological thought.

With this analysis, the relation of Albertus's astrological magic to his philosophy becomes more vivid. Yet, it also poses the question of why Albertus keeps insisting on making allusions to magic and not stating his opinion openly, no matter how radical it may be. With the aim of answering this question I will provide arguments, which mostly depict my personal views upon this subject.

The first thing we have to take under consideration in Albertus's case is the intellectual and social environment within which he attempted to convey his ideas. By that time, the art of necromancy and the heresy of Catharism posed important difficulties for clerics, mainly because these two factors exposed them to the accusation of practicing demonology ${ }^{25}$. In particular, a religious-magic stereotype began to be formulated by folk literature, resulting in the clerics being associated with necromancy, mostly due to their knowledge of Latin. Latin was the key for invoking a demon or performing an exorcism. On one hand, the worst thing was that astral magic was needed in order to ensure a better outcome. On the other hand,

22 Super Ethica, xiv/1: «Voluntas autem, quae est principium nostrorum operum, quibus sumus boni vel mali, est potentia animae rationalis, et sic patet quod non necessario sumus boni vel mali ex dispositione nativitatis secundum effectus stellarum, sed quod tantum relinquuntur ex eis dispositiones in natura corporis...»

23 De mineralibus, II, caput 3, tr.iii : »Est enim in homine duplex principium operum, natura scilicet et voluntas: et natura quidem regitur sideribus, voluntas quidem libera est: sed nisi renitatur, trahitur a natura et induratur, et cum natura moveatur motibus siderum, incipit voluntas tunc admotus siderum et figuras inclinari.»

24 Korolec, J. B., «Free Will and Free Choice», in Norman Kretzmann, Antony Kenny and Jan Pinborg (ed.), The Cambridge History of Later Medieval Philosophy, from the Rediscovery of Aristotle to the Disintegration of Scholasticism 1100-1600, Cambridge, Cambridge University Press, 1982, pp. 634-635.

25 Russell, J. B., Witchcraft in the Middle Ages, Ithaca and London, Cornell University Press, 1972, pp. $120-132$. 
Catharism was an imminent threat to the Church, since their tenets opposed the basic beliefs of Catholic faith and proclaimed a dualism, where Satan was presented as an almost equal entity to God. Prima facie, there seems to be no overt connection between these two facts, yet historical data will shed more light on the case. In 1231, Pope Gregory IX established the Inquisition in order to deal with heresies. Furthermore, in 1252 Pope Innocent IV allowed papal inquisitors to use torture in order to extract information from suspects; and four years later Pope Alexander IV ordered that inquisitors must not get involved in cases of magic which concern divination or sorcery, unless these magical practices involved a drive to heretical outcomes ${ }^{26}$. Now, under these terms, Albertus Magnus would not feel that comfortable to clearly express his positive attitude towards natural magic, because he would consequently have to explain how such an art, that has an astrological basis, avoids suspicion of illicit divination and demonic involvement. Unless he succeeded, he would put himself in danger of being convicted either as a heretic or as a necromancer.

But even if Albertus wanted to prove the validity of natural magic, to my mind, he would not be able to do so, and the reason for this lies in the very same foundations of his science: Aristotelianism. During the $13^{\text {th }}$ century Aristotelianism was neither fully assimilated as a scientific doctrine nor perfectly reconciled with Christian faith. Indeed, there is plenty of evidence that points to the contrary. As early as 1210 and 1215, Aristotelian natural philosophy encounterd hindrance, something which would be repeated later with the famous condemnations of 1270 and 1277 by the bishop of Paris, Etienne Tempier ${ }^{27}$. These reactions against Aristotle unveil the controversy that was deployed between philosophy and religion during that age. Simultaneously, one may interpret this intervention from the Church as an effort to prevent the establishment of a «double truth». That is to say, to prevent theological or natural matters being explained by philosophical arguments as well as by faith. As we have already seen, Albertus' natural magic has a strong scientific foundation, which derives from an Aristotelian-based astrology. Given the controversy described before, it would not be easy for Albertus to justify natural magic without objections. However, an even bigger problem emerges for the German philosopher, that is, his attempt to analyse the way natural magic works using the scientific method. According to Aristotle's philosophy, there must be material contact between the mover and the moved in order to explain the effect which comes from a certain cause ${ }^{28}$. So, it becomes easily comprehensible how such notions as «celestial influence» and «occult virtues» are not subject to an Aristotelian cause-effect analysis. That is, provided there is no constant contact between cause and effect; and apparently it is quite dubious whether the afore-mentioned contact is material ${ }^{29}$. It is clear that Albertus Magnus had high-level scientific consciousness. Perhaps he soon realized that, despite the empirical data and the results of his observations, a rationalization of magic was not possible, if done under these conditions.

Lastly, there is one more factor that may be taken under consideration: the religious tra-

26 Bailey, Michael D., Magic and Superstition in Europe: A Concise History from Antiquity to the Present, Lanham, Rowman and Littlefield Publishers, inc, 2007, pp. 116-119.

27 About the subject see Wippel, John F., «The Condemnations of 1270 and 1277 at Paris», Journal of Medieval and Renaissance Studies, 7 (1977), pp. 169-201; for its relation to cosmology, astronomy and astrology see Grant, Edward, Planets, Stars and Orbs, The Medieval Cosmos 1200-1600, New York, Cambridge University Press, 1996, pp. 47-55.

28 Aristotle, Physica, Г, 201a.

29 Wallace, William A., «The Scientific Methodology of St. Albert the Great», in Gerbert Meyer and Albert Zimmermann (ed.), Albertus Magnus -Doctor Universalis 1280/1980, Mainz: Matthias Gruenewald Verlag, 1980, pp. 391-392. 
dition, which seemed to have had a profound influence on Albertus Magnus. In particular, the opinions about magic, expressed by authorities such as Augustine, Isidore of Seville and Peter Lomabard, seemed to have grown strong roots in the thought of Albertus Magnus. For example, in Albertus's effort to explain how demons act and have the capacity to deceive the human senses, one may discern the intellectual influence from ideas that were entrenched in the thought of Augustine and Peter Lombard ${ }^{30}$. Additionally, Albertus followed the same line of thinking in order to justify the superiority of the angels in relation to demons, and to show the difference between angelic miracles and demonic deception ${ }^{31}$. The examples, of course, are far more abundant and scattered all over the work of the German philosopher, but suffice to say that one must bear in mind that this tradition is not to be taken lightly. Given this fact, it would seem odd and inexplicable on Albertus's part to abandon his religious-cultural environment in such a radical and perhaps provocative way, purely to display magic as an innovative form of knowledge. Nonetheless, if he had, the reactions would have been massively and malevolently directed against him.

In conclusion, the scrutiny of the sources indicates that we must rely on Albertus's genuine works, in order to decide his relation to magic. In his theological works, he attempts to present a new kind of Magus whose art derives from nature and whose magical knowledge is associated with philosophy. On the one hand, this new Magus lays claim to a persona grata both within the Church and amongst scholars. On the other hand, the natural works of Albertus Magnus provide us with satisfactory citations that permit us to connect magic with philosophy. This connection is accomplished in terms of astrology, wherein philosophical doctrines of cosmology, psychology and ethics meet magic, in order to provide a more natural legitimized version of the latter. A clear and sound statement from Albertus Magnus in favour of magic would not be possible in that epoch, mainly due to the intellectual and social environment and the lack of scientific methodology in magic.

\section{BIBLIOGRAPHY}

Albertus, Magnus, Opera omnia, ex editione lugdunensi, religiose castigata, et pro auctoritatibus ad fidem vulgatae versionis accuratiorumque patrologiae textuum revocata, auctaque B. Alberti vita ac Bibliographia suorum operum a PP. Quetif et Echard exaratis etiam revisa et locupletata cura et labore A. Borgnet. 38 vols. Paris: 1890-99.

Anzulewicz, Henryk, «Magie im Verständnis Alberts des Grossen.» In Mots Médiévaux offerts à Ruedi Imbach, I. Atucha, D. Calma, C. König-Pralong and I. Zavattero (ed.), Porto: 2011, 419-431.

Aristotle, The Physics. Tr. Philip H. Wicksteed and Francis M. Cornford. 2 vols. Cambridge, 1957.

Bailey, Michael D., Magic and Superstition in Europe: A Concise History from Antiquity to the Present. Lanham: Rowman and Littlefield Publishers, Inc, 2007.

Burnett, Charles, «Talismans: Magic as Science? Necromancy among the Seven Liberal Arts.» In Magic and Divination in the Middle Ages: Texts and Techniques in the Islamic and Christian Worlds, ed. Charles Burnett, Aldershot, 1996, 1-15.

30 Henryk Anzulewicz, «Magie imVerständnis Alberts des Grossen» in I. Atucha, D. Calma, C. KönigPralong and I. Zavattero (ed.), Mots Médiévaux offerts à Ruedi Imbach, Porto: 2011, p. 420.

31 Ibid., p. 423. 
Collins, David J., «Albertus Magnus or Magus? Magic, Natural Philosophy and Religious Reform in the Late Middle Ages.» Renaissance Quarterly 63/1 (2010): 1-44.

Grant, Edward, Planets, Stars and Orbs, The Medieval Cosmos 1200-1600. New York: Cambridge University Press, 1996.

Korolec, B. J., «Free Will and Free Choice.» In The Cambridge History of Later Medieval Philosophy, from the Rediscovery of Aristotle to the Disintegration of Scholasticism 1100-1600, ed. Norman Kretzmann, Antony Kenny and Jan Pinborg, Cambridge: Cambridge University Press, 1982, 629-641.

Russell, J. B., Witchcraft in the Middle Ages. Ithaca and London: Cornell University Press, 1972.

Rutkin, Darrel H., «Astrology and Magic.» In A Companion to Albert the Great: Theology, Philosophy and the Sciences, ed. Irven M. Resnick, Leiden-Boston: Brill, 2013, 451-505.

Sighart, Joachim, Trans. T. A. Dixon. Albert the Great of the Friar Preachers: His Life and Scholastic Labours. London: R. Washbourne, 1876.

Thorndike, Lynn, A History of Magic and Experimental Science, vol. II. New York: Columbia University Press, 1923.

Wallace, William A., «The Scientific Methodology of St. Albert the Great.» In Albertus Magnus- Doctor Universalis 1280/1980, ed. Gerbert Meyer and Albert Zimmermann, Mainz: Matthias Gruenewald Verlag, 1980, 385-407.

Weisheipl, James A., «The Life and Works of St. Albert the Great.»In Albertus Magnus and the Sciences: Commemorative Essays 1980, ed. James A. Weisheipl, Toronto: Pontifical Institute of Mediaeval Studies, 1980, 13-52.

Williams, Steven J., «Defining the Corpus Aristotelicum: Scholastic Awareness of Aristotelian Spuria in the High Middle Ages.» Journal of the Warburg and Courtauld Institutes 58 (1995): 29-51.

Wippel, John F., «The Condemnations of 1270 and 1277 at Paris.» Journal of Medieval and Renaissance Studies 7 (1977): 169-201.

Zambelli, Paola, The Speculum astronomiae and its Enigma: Astrology, Theology and Science in Albertus Magnus and his Contemporaries. Dordrecht: Kluwer Academic Publishers, 1992.

Zambelli, Paola, White Magic, Black Magic in the European Renaissance. Leiden: Brill, 2007.

Fecha de recepción: día 20 de abril de 2015

thrinotas@yahoo.gr

Fecha de aceptación: día 9 de septiembre de 2015 